\title{
U.S. Geological Survey and Bureau of Land Management Cooperative Coalbed Methane Project in the Powder River Basin, Wyoming
}

\section{Introduction}

The Bureau of Land Management (BLM) Wyoming Reservoir Management Group and the U.S. Geological Survey (USGS) began a cooperative project in 1999 to collect technical and analytical data on coalbed methane $(\mathrm{CBM})$ resources and quality of the water produced from coalbeds in the Wyoming part of the Powder River Basin. The agencies have complementary but divergent goals and these kinds of data are essential to accomplish their respective resource evaluation and management tasks. The project also addresses the general public need for information pertaining to Powder River Basin CBM resources and development.

BLM needs, which relate primarily to the management of CBM resources, include improved gas content and gas in-place estimates for reservoir characterization and resource/reserve assessment, evaluation, and utilization. USGS goals include a basinwide assessment of CBM resources, an improved understanding of the nature and origin of coalbed gases and formation waters, and the development of predictive models for the assessment of CBM resources that can be used for such purposes in other basins in the United States (for example, the Bighorn, Greater Green River, and Williston Basins) and in other countries throughout the world (for example, Indonesia, New Zealand, and the Philippines).

Samples of coal, produced water, and gas from coalbed methane drill holes throughout the Powder River Basin, many of which are adjacent to several active mine areas (figs. 1,2), have been collected by personnel in the USGS, BLM Reservoir Management Group, and Casper and Buffalo BLM Field Offices. Sampling was done under confidentiality agreements with 29 participating CBM companies and operators. Analyses run on the samples include coal permeability, coal quality and chemistry, coal petrography and petrology, methane desorption and adsorption, produced-water chemistry, and gas composition

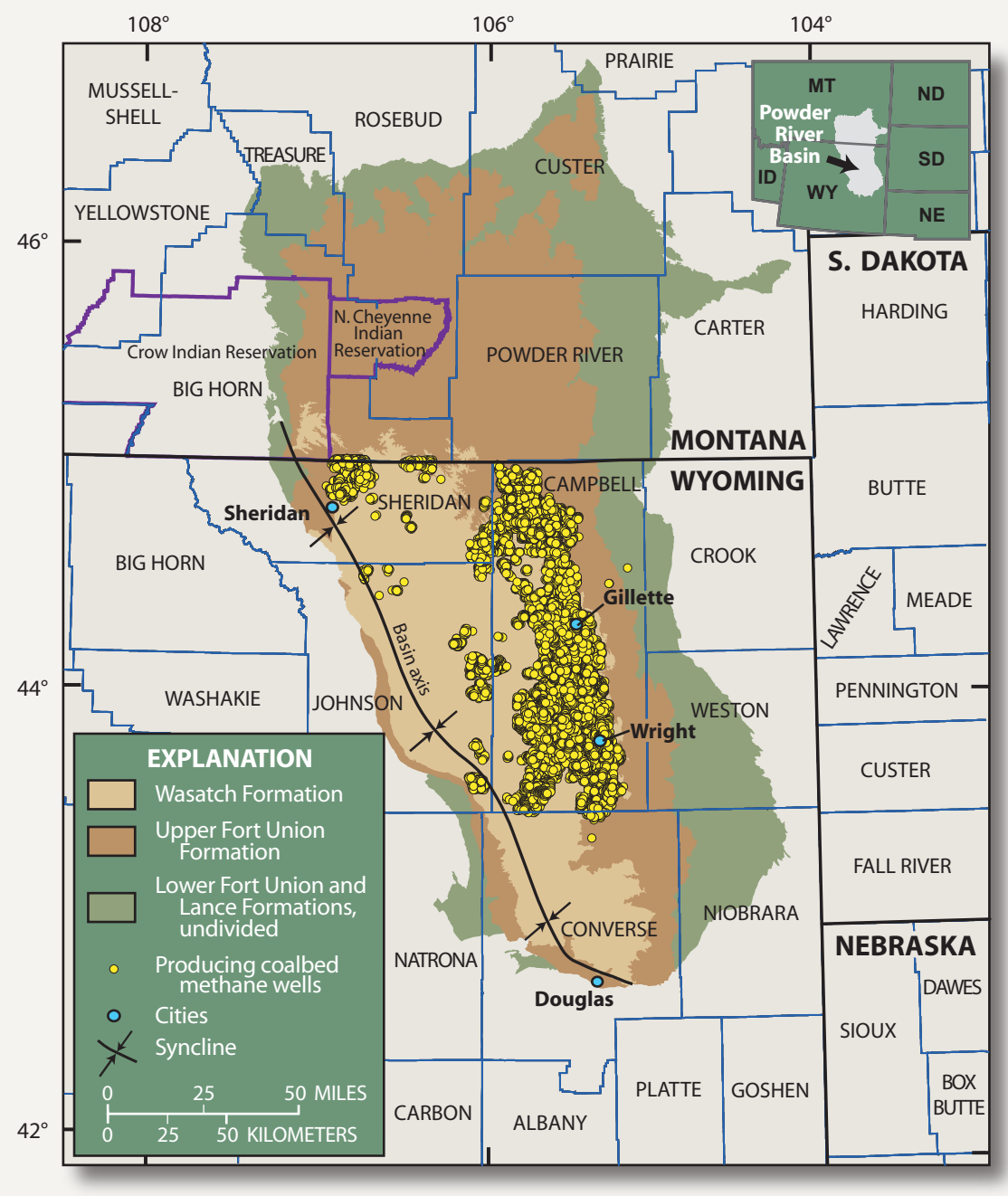

Figure 1. Producing coalbed methane wells in the Wyoming part of the Powder River Basin. Locations from Wyoming Oil and Gas Conservation Commission (2006).

and isotopes. The USGS has supplied results to the BLM Reservoir Management Group for their resource management needs, and data are released when the terms of the confidentiality agreements are completed and consent is obtained. 


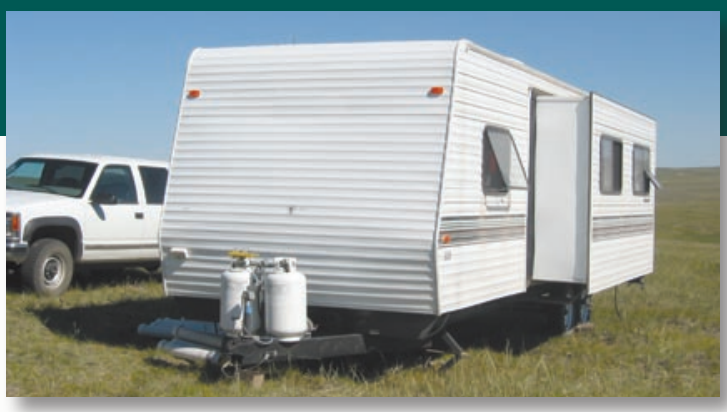

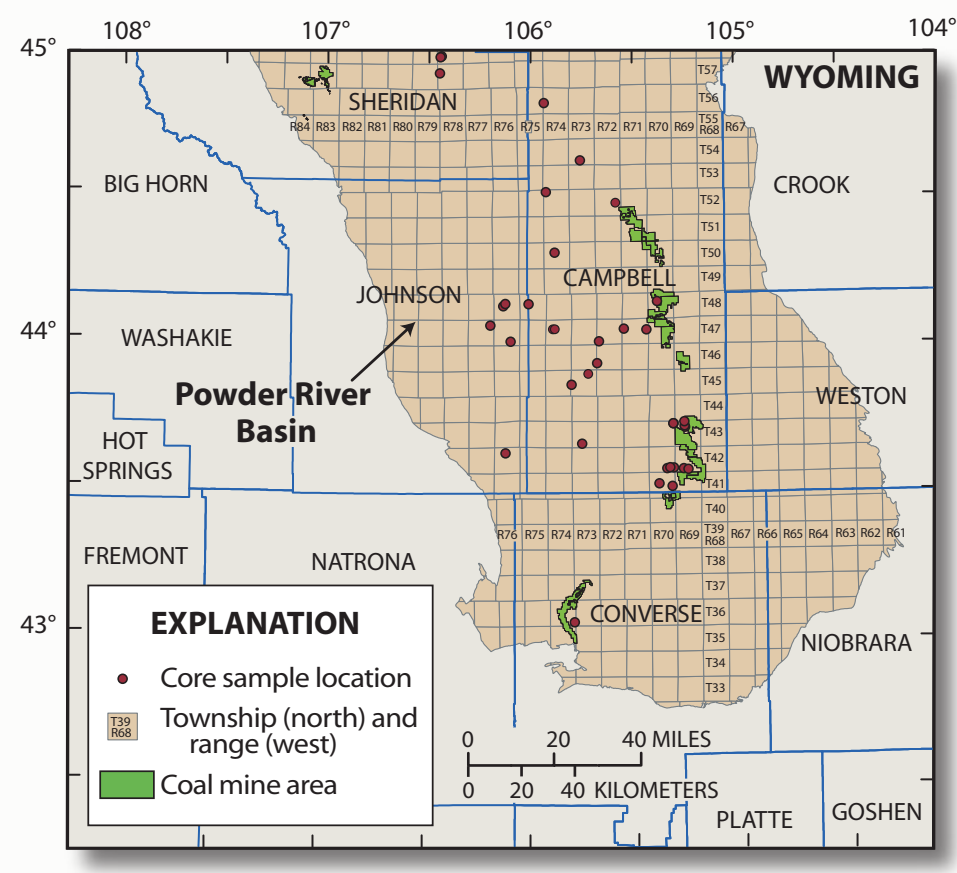

Figure 2. Locations of cored coalbed methane drill holes in the Wyoming part of the Powder River Basin.

\section{Samples from Coal Core}

The Bureau of Land Management provides and maintains a wet lab (fig. 3) that is used for desorption of coal core at the well site. Core is collected and cut into 2-ft-long sections (fig. 4) and sealed in canisters for gas desorption. Information is recorded at the drill site to allow for calculation of the amount of gas lost from each of the core segments prior to being sealed in the canisters. The sealed canisters are placed in a temperature-controlled water bath (fig. 5) to simulate reservoir temperature of the coal at depth. Desorption readings are recorded at 15-minute intervals for the first nine hours (fig. 6), then are taken at progressively longer intervals until the time period between readings is long enough to allow for transport of the canisters to our USGS laboratory in Denver, Colo.

Coal samples are desorbed in the USGS laboratory until little or no gas is detected for an extended period of time. Gas and coal samples from selected wells are sent for isotopic analysis and high pressure methane adsorption analysis (respectively). Cores are sent to the USGS laboratory in Reston, Va. where they are described and analyzed for macerals. They are then provided to a contract laboratory for proximate, ultimate, and calorific analysis.

To date, samples have been obtained from 38 coalbed methane wells in the Wyoming part of the Powder River Basin (fig. 2). Desorption of gas and coal analyses were run on coal core from 838 canisters. Additionally, gas compositions and isotopes were determined for more than 100 samples and adsorption isotherms were completed for 73 samples.
Figure 3. Bureau of Land Management Wyoming Reservoir Management Group wet lab used for methane desorption of coal core.

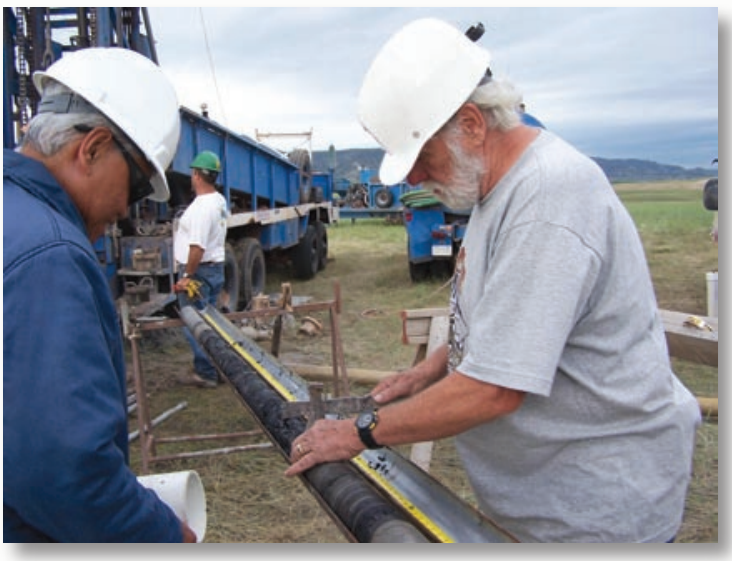

Figure 4. Collection of coal core.

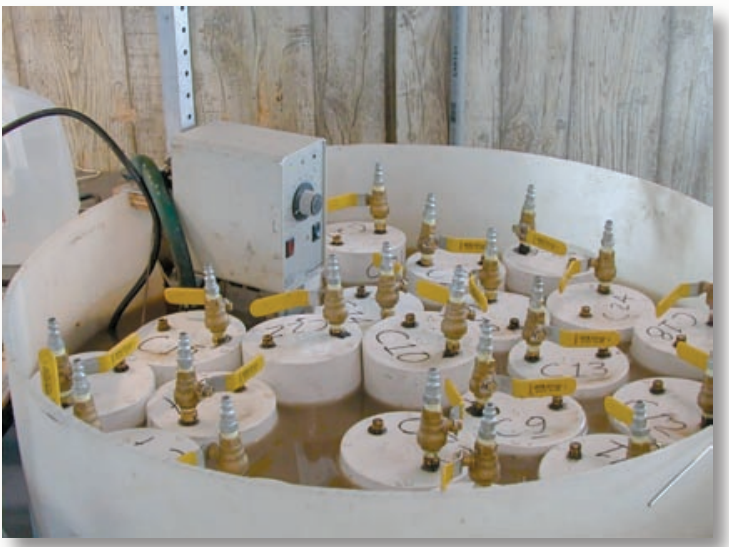

Figure 5. Coal canisters in temperature-controlled water bath.

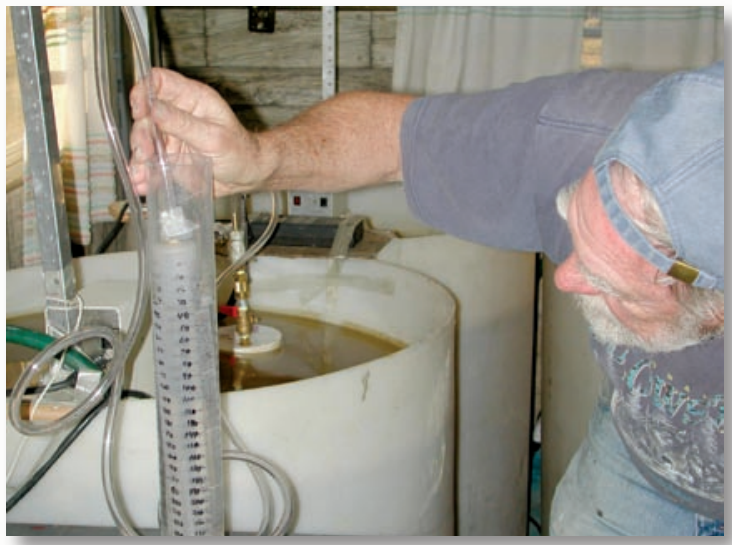

Figure 6. Measuring desorbed gas from the coal canisters. 


\section{Produced Water from CBM Wells}

Produced-water samples were obtained through tubing attached directly to CBM wellhead ports. Tubing was flushed thoroughly and samples were collected following the guidelines of Lico and others (1982). Field and laboratory measurements include $\mathrm{pH}$, temperature, conductivity, alkalinity, dissolved oxygen, and ferrous/ total iron. Preserved samples were analyzed for major, minor, and trace cations and metals and for anions. Deuterium and oxygen isotopes were analyzed by an outside laboratory.

Sample analyses (table 1) indicate that CBMproduced water from the Paleocene Fort Union Formation is sodium bicarbonate-type water and has relatively low total dissolved solids (TDS) compared to most oil and gas production water, as well as to other CBM-produced water. Produced water from the Powder River Basin is reducing, which allows relatively high concentrations of redox-sensitive metals such as iron and manganese. Other trace metal concentrations, except for barium, are uniformly low. Low sulfate concentrations in almost all produced water in the Powder River Basin reflect the process of sulfate reduction, which allows for relatively high concentrations of barium compared to most ground water. CBM-produced water can have high sodium absorption ratios (SAR) because of the high sodium content relative to the low calcium and magnesium concentrations. High SARs may be an issue that must be addressed if surface disposal is an option. Other constituents in CBM-produced water, such as ammonia, may also be a concern for certain types of disposal options.

The composition of produced water in the Powder River Basin reflects the evolution of meteoric water subjected to geochemical processes and reactions along both horizontal and vertical flow paths. Compositional analyses of CBM-produced water exhibit areal trends for water from both individual coalbeds and for all coalbeds sampled from a given formation. Trends in TDS, SAR, and iron in produced water from coalbeds sampled from the Fort Union Formation and from the Eocene Wasatch Formation are shown in figure 7 . These trends indicate that the composition of water from coalbeds in the Fort Union Formation is changing down long, regional flow paths rather than shorter, localized flow paths. Some horizontal and vertical variations in produced-water composition, however, indicate a more intricate interpretation that may be because of complex coal stratigraphy and (or) the possible misidentification of some of the coalbeds sampled. Additional analyses should clarify many of these relations.
Table 1. Composition of produced water from coal in the Wasatch and Fort Union Formations in the Wyoming part of the Powder River Basin compared to the drinking water standard. (Note: Trends in total dissolved solids, sodium absorption ratio, and iron are shown in fig. 7)

[SAR, sodium absorption ratio; TDS, total dissolved solids; NC, not calculated; NA, not applicable; *, recommendation only; mg/L, milligram per liter; and $\mu \mathrm{g} / \mathrm{L}$, microgram per liter]

\begin{tabular}{|c|c|c|c|c|c|}
\hline & \multicolumn{2}{|c|}{$\begin{array}{l}\text { Wasatch Formation } \\
\text { Produced Water } \\
(n=8)\end{array}$} & \multicolumn{2}{|c|}{$\begin{array}{l}\text { Fort Union Formation } \\
\text { Produced Water } \\
(n=174)\end{array}$} & \multirow[t]{2}{*}{$\begin{array}{l}\text { Drinking } \\
\text { Water } \\
\text { Standard }\end{array}$} \\
\hline & Range & Average & Range & Average & \\
\hline $\mathrm{pH}$ & $7.0-8.2$ & 7.6 & $6.6-8.0$ & 7.3 & $6.5-8.5^{*}$ \\
\hline \multirow[t]{2}{*}{ SAR } & $7-24$ & 18 & $5.6-69$ & 20 & NA \\
\hline & \multicolumn{2}{|c|}{$\mathrm{mg} / \mathrm{L}$} & \multicolumn{2}{|c|}{$\underline{\mathrm{mg} / \mathrm{L}}$} & \\
\hline TDS & $530-3,010$ & 1,420 & $270-2,800$ & 1,050 & $500^{*}$ \\
\hline Chloride & $3.4-24$ & 14 & 5.1-130 & 14 & $250^{*}$ \\
\hline Sulfate & $6.2-1,450$ & 380 & $<0.03-530$ & 5.4 & $250^{*}$ \\
\hline Bicarbonate & $500-1,720$ & 980 & $290-3,140$ & 1,280 & NA \\
\hline Calcium & $6.0-74$ & 25 & $1.8-78$ & 29 & NA \\
\hline Potassium & $2.3-59$ & 12 & $3.1-58$ & 12 & NA \\
\hline Magnesium & $2.2-122$ & 27 & $0.6-46$ & 6 & NA \\
\hline \multirow[t]{3}{*}{ Sodium } & $210-730$ & 440 & $110-1,100$ & 430 & NA \\
\hline & Range & Average & Range & Average & \\
\hline & \multicolumn{2}{|c|}{$\underline{\mu g} / \mathrm{L}$} & \multicolumn{2}{|c|}{$\underline{\mu \mathrm{q} / \mathrm{L}}$} & \\
\hline Iron & $24-850$ & 330 & $20-17,500$ & 1,720 & $300^{*}$ \\
\hline Manganese & 5.9-68 & 25 & $1.4-350$ & 34 & $50^{*}$ \\
\hline Arsenic & $<0.2-1.8$ & NC & $<0.2-4.1$ & $\mathrm{NC}$ & 50 \\
\hline Barium & $90-320$ & 170 & $14-2,710$ & 730 & 2,000 \\
\hline Cadmium & $<0.1$ & $<0.1$ & $<0.1$ & $<0.1$ & 5 \\
\hline Chromium & $<1$ & $<1$ & $<0.1-8.8$ & NC & 100 \\
\hline Copper & $0.28-0.97$ & 0.53 & $0.11-2.9$ & $\mathrm{NC}$ & 1,300 \\
\hline Lead & $<0.5$ & $<0.5$ & $<0.1-0.43$ & $\mathrm{NC}$ & 15 \\
\hline Mercury & $<0.1$ & $<0.1$ & $<0.005-0.25$ & $\mathrm{NC}$ & 2 \\
\hline Selenium & $<1$ & $<1$ & $<2-8$ & NC & 50 \\
\hline Zinc & $<1-24$ & 6.4 & $<1-80$ & $\mathrm{NC}$ & $5,000^{*}$ \\
\hline
\end{tabular}




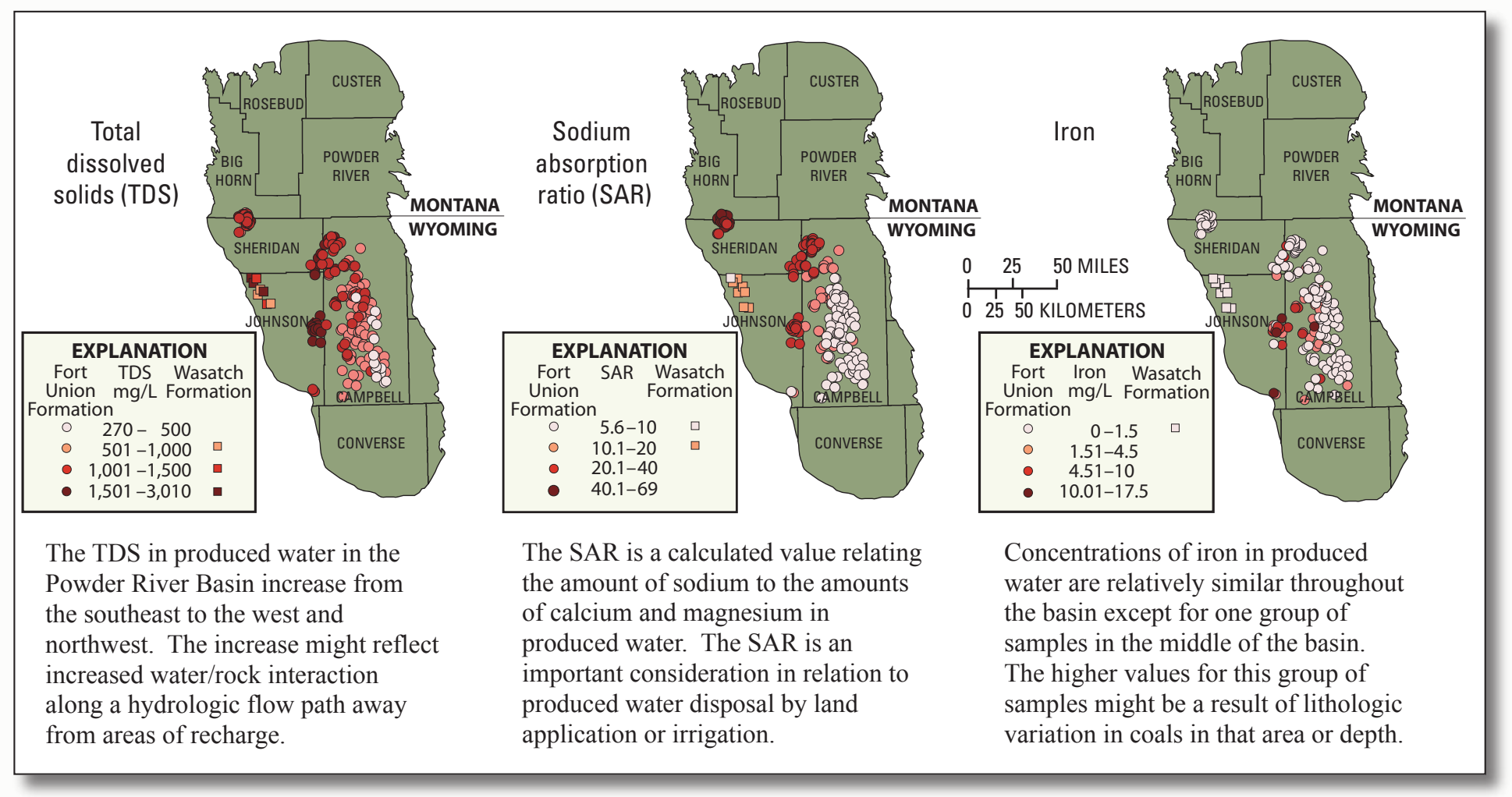

Figure 7. Areal distribution of total dissolved solids, sodium absorption ratio, and iron in produced-water samples from the Fort Union and Wasatch Formations in the Powder River Basin.

\section{Applications}

Applications and benefits of data from this study are numerous. In addition to the use of the information generated to accomplish Federal CBM resource evaluation and management missions and to address public needs, the data are also synthesized and published by the USGS to benefit industry, academia, consultants, other Federal agencies, and State and local governments (see, for example, Flores, 2004; Stricker and others, 2006).

Some BLM applications of the data resulting from this study include (1) producing recoverable gas reserve estimates for resource management (Crockett and others, 2001), planning, and Environmental Impact Study; (2) estimating drainage and depletion of CBM resources (Crockett, 2004); (3) addressing and resolving issues between CBM development and coal mining that have resulted from the drainage of CBM resources; (4) ground-water modeling; (5) coal-reservoir analysis, characterization, and modeling; and (6) providing support of coal leasing and mine development in adjoining CBM leases (McGarry, 2005a-d).

The USGS uses the data to (1) perform coalbed gassaturation analysis (Stricker and Flores, 2002); (2) study the occurrence and distribution of economically minable coal; (3) determine the potential for $\mathrm{CO}_{2}$ sequestration using $\mathrm{CO}_{2}$ and $\mathrm{CH}_{4}$ adsorption-isotherm data (Stricker and Flores, 2003, 2004); (4) define the extent, distribution, and character of coal reservoirs (McGarry and Flores, 2004); (5) determine the origin of CBM in the basin (for example, microbial studies by Klein and others, 2004, 2005; Stricker and others, 2006); (6) study the evolution of produced water; and (7) provide produced-water quality information to the public (Rice and others, 2000, 2002). This study has expanded into other basin areas in Wyoming and has resulted in additional studies in North Dakota and in other parts of the world as interest in, and the need for, additional CBM data has increased. 


\section{Acknowledgments}

This study would not have been possible without the cooperation of many companies and operators in the Powder River Basin who allowed USGS and BLM workers to collect coal core, gas, and produced-water samples from their CBM wells (fig. 8). These companies include: Ammonite Energy Texas, Inc.; Anadarko Petroleum; Barrett Resources Corp.; Big Basin Petroleum; Bill Barrett Corp.; Conquest Energy; CMS Energy; Fidelity Company; Hi-Pro Production; Jacobs Ranch Coal Company; J.M. Huber Corporation; Kennecott Energy; Kennedy Oil; Lance Oil and Gas; Quantum Energy LLC; Marathon Oil; MichiWest Energy; Nance Petroleum; Ocean Energy; Pacific Minerals, Inc.; Peabody Natural Gas; Pennaco Energy; Redstone Gas Partners; Rim Operating Company; Thunder Basin Operating Company; Western Gas Resources; Williams Company; Williams Exploration and Production; and Yates Petroleum Corp.

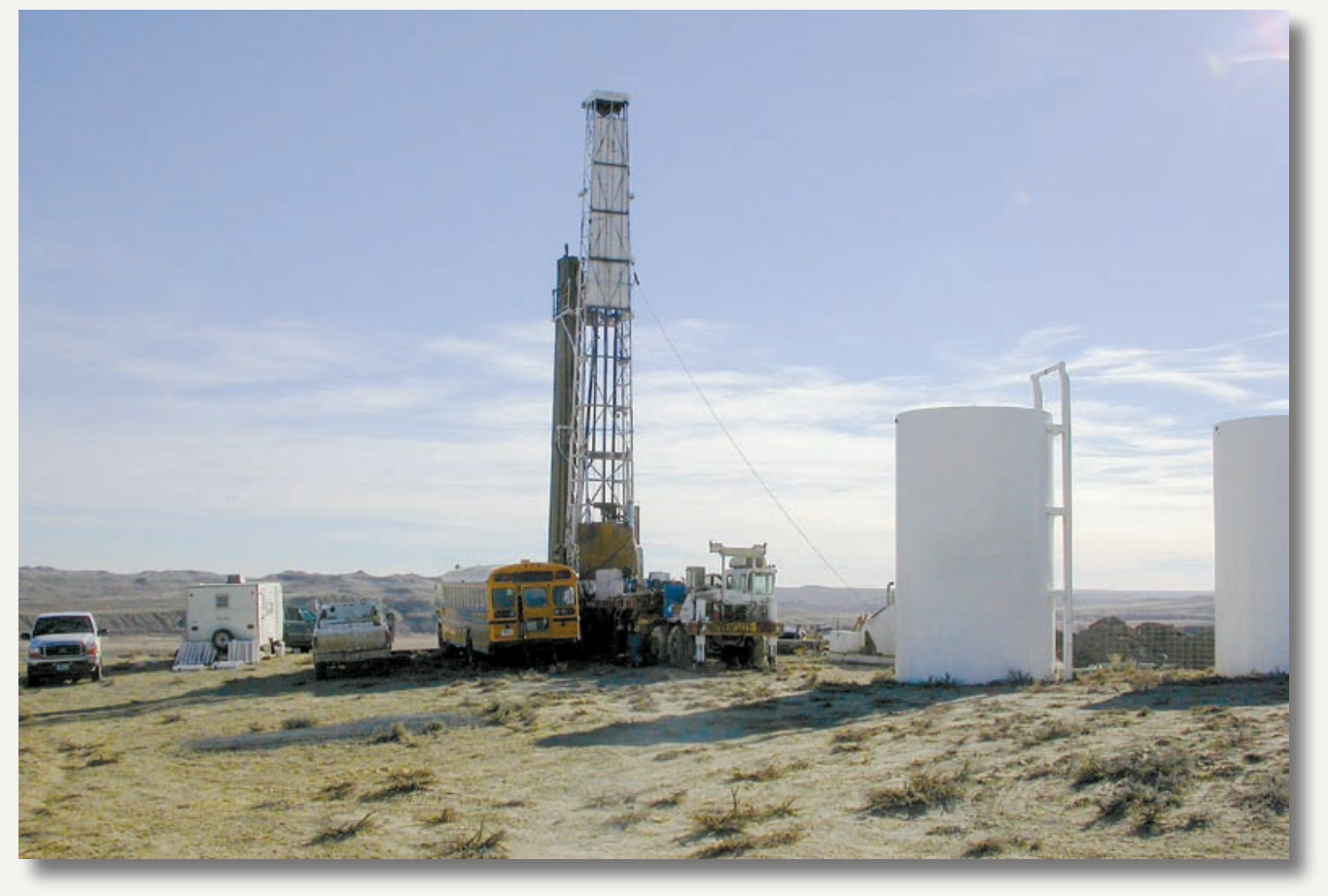

Figure 8. Drill site near Kaycee, Wyo. Bighorn Mountains in the background.

\section{References Cited}

Crockett, F., 2004, Review of drainage of Federal minerals due to coalbed natural gas development in the Powder River Basin: Bureau of Land Management, Wyoming Reservoir Management Group, Internal Study, Bureau of Land Management files, $1 \mathrm{p}$.

Crockett, F.J., Ellis, M.S., Stricker, G.D., Gunther, G.L., Ochs, A.M., and Flores, R.M., 2001, An Estimate of Coal Gas Resources in the Powder River Basin, Wyoming: Wyoming Geological Association 52nd Field Conference Guidebook 2001-Wyoming Gas Resources and Technology, Extended Abstract, p. 183-189.

Flores, R.M., 2004, Coalbed methane in the Powder River Basin, Wyoming and Montana: An assessment of the Tertiary-Upper Cretaceous coalbed methane Total Petroleum System, in Total Petroleum System and Assessment of Coalbed Gas in the Powder River Basin Province, Wyoming and Montana: U.S. Geological Survey Digital Data Series DDS-69-C, version 1, chap. 2, $56 \mathrm{p}$.
Klein, D.A., Flores, R.M., McKinney S., Pereyra, L.P., and Pruden, A., 2005, Cultural and molecular studies of methanogens in Paleocene Fort Union Formation coal from the Powder River Basin of Wyoming and Montana: American Association of Petroleum Geologists 2005 Rocky Mountain Section-AAPG Jackson Hole Meeting, Jackson Hole, Wyoming, September 24-26, 2005, Meeting Program, p. 35-36.

Klein, D.A., Flores, R.M., Pereyra, L.P., and Pruden, A., 2004, Putative methanogen molecular evidence in Paleocene Fort Union coals in the Powder River Basin, Wyoming and Montana: Geological Society of America Annual Meeting, November 7-10, 2004, Denver, Colorado, Abstracts with Programs, v. 36, no. 5, p. 84.

Lico, M.S., Kharaka, Y.K., Carothers, W.W., and Wright, V.A., 1982, Methods for collection and analysis of geopressured geothermal and oil field waters: U.S. Geological Survey Water Supply Paper 2194, 21 p. 
McGarry, D.E., 2005a, Review of coalbed methane gas and conventional oil and gas resources, production, and economics, Bureau of Land Management, Wyoming Reservoir Management Group LBA Draft Environmental Impact Statements for the North Antelope-Rochelle mine area, 10 p.

McGarry, D.E., 2005b, Review of coalbed methane gas and conventional oil and gas resources, production, and economics, Bureau of Land Management, Wyoming Reservoir Management Group LBA Draft Environmental Impact Statements for the Buckskin mine area, $10 \mathrm{p}$.

McGarry, D.E., 2005c, Review of coalbed methane gas and conventional oil and gas resources, production, and economics, Bureau of Land Management, Wyoming Reservoir Management Group LBA Draft Environmental Impact Statements for the West Antelope mine area, $10 \mathrm{p}$.

McGarry, D.E., 2005d, Review of coalbed methane gas and conventional oil and gas resources, production, and economics, Bureau of Land Management, Wyoming Reservoir Management Group LBA Draft Environmental Impact Statements for the Maysdorf area (near Cordero-Rojo and Caballo Mines), $10 \mathrm{p}$.

McGarry, D.E., and Flores, R.M., 2004, Hydrodynamic and stratigraphic controls on Wyodak-Anderson coalbed natural gas reservoirs in the Fort Union Formation, Powder River Basin, Wyoming: AAPG Rocky Mountain Section MeetingRocky Mountain Natural Gas 2004, Denver, Colo. August 9-11, 2004, website at http://www.mines.edu/Research/ PTTC/CBM/fortunion/index.html.

Rice, C.A., Bartos, T.T., and Ellis, M.S., 2002, Chemical and isotopic composition of water in the Fort Union and Wasatch Formations of the Powder River Basin, Wyoming and Montana: Implications for coalbed methane development: The Rocky Mountain Association of Geologists, Coalbed Methane of North America II, p. 53-70.

Rice, C.A., Ellis, M.S., and Bullock, J.H., Jr., 2000, Water coproduced with coalbed methane in the Powder River Basin, Wyoming: Preliminary compositional data: U.S. Geological Survey Open-File Report 00-372, 20 p.

Stricker, G.D., and Flores, R.M., 2002, Coalbed methane content in the Powder River Basin, Wyoming: Saturation by coal rank and depth: Nineteenth Annual International Pittsburgh Coal Conference Proceedings, Pittsburgh, Pennsylvania, September 22-27, 2002, Session 6, CD-ROM, 15 p.

Stricker, G.D., and Flores, R.M., 2003, Potential carbon dioxide sequestration and enhanced coalbed methane production in the Powder River and Williston Basins, in Sakkestad, B.A., ed., Proceedings of the 29th International Technical Conference on Coal Utilization and Fuel Systems, CD-ROM, p. 387-402.

Stricker, G.D., and Flores, R.M., 2004, Assessment of carbon dioxide sequestration in Fort Union coal beds in the northern Rocky Mountains-Great Plains coal basins: Geological
Society of America Annual Meeting, November 7-10, 2004, Denver, Colorado, Abstracts with Programs, v. 36, no. 5, p. 541 .

Stricker, G.D., Flores, R.M., Klein, D.A., Rice, C.A., and Schmidt, R.A., 2006, Shallowest coalbed accumulation in the west: It's all about water and microbes in the Powder River Basin: American Association of Petroleum Geologists, April 9-12, 2006, Abstracts Volume, p. 102.

Stricker, G.D., Flores, R.M., McGarry, D.E., Stillwell, D.P., Hoppe, D.J., Stillwell, C.R., Ochs, A.M., Ellis, M.S., Osvald, K.S., Taylor, S.L., Thorvaldson, M.C., Trippi, M.H., Grose, S.D., Crockett, F.J., and Shariff, A.J., 2006, Gas desorption and adsorption isotherm studies of coals in the Powder River Basin and adjoining basins in Wyoming and North Dakota: U.S. Geological Survey Open-File Report 06-1174, 250 p.

Wyoming Oil and Gas Conservation Commission, 2006, website at http://wogcc.state.wy.us.

\section{Additional Information}

Links to additional publications that used data from this cooperative study are available on the USGS Central Energy Team website at http://energy.cr.usgs.gov/oilgas/cbmethane/ and on the Wyoming BLM website at http://www.wy.blm.gov/ minerals/og/ogcbm.htm.

\section{Contacts}

\section{U.S. Geological Survey}

Romeo M. Flores, Project Chief, U.S. Geological Survey Central Energy Resources Team, Denver, Colo., Phone: (303) 236-7774, Email: rflores@usgs.gov

Gary D. Stricker, U.S. Geological Survey Central Energy Resources Team, Denver, Colo., Phone: (303) 236-7763

Cyndi A. Rice, U.S. Geological Survey Central Energy Resources Team, Denver, Colo., Phone: (303) 236-1989, Email: crice@usgs.gov

Margaret S. Ellis, U.S. Geological Survey Central Energy Resources Team, Denver, Colo., Phone: (303) 236-7775, Email: mellis@usgs.gov

\section{Bureau of Land Management}

Karl S. Osvald, Project Chief, Bureau Land Management Wyoming Reservoir Management Group, Casper, Wyo., Phone: (307) 261-7729, Email: Karl_Osvald@blm.gov

Dwain E. McGarry, Bureau of Land Management Wyoming Reservoir Management Group, Casper, Wyo., Phone: (307) 261-7624, Email: Dwain_McGarry@blm.gov 